\title{
Environment and morphology of mesoscale convective systems associated with the Changma front during 9-10 July 2007
}

\author{
J.-H. Jeong ${ }^{1}$, D.-I. Lee ${ }^{1}$, C.-C. Wang ${ }^{2}$, S.-M. Jang ${ }^{1}$, C.-H. You ${ }^{3}$, and M. Jang ${ }^{4}$ \\ ${ }^{1}$ Department of Environmental Atmospheric Sciences, Pukyong National University, Busan, South Korea \\ ${ }^{2}$ Department of Earth Sciences, National Taiwan Normal University, Taipei, Taiwan \\ ${ }^{3}$ Radar Analysis Division, Weather Radar Center, KMA,Seoul, South Korea \\ ${ }^{4}$ Applied Meteorology R\&D Center, Weatherlink INC., SungNam, South Korea
}

Correspondence to: D.-I. Lee (leedi@ pknu.ac.kr)

Received: 3 December 2011 - Revised: 3 July 2012 - Accepted: 20 July 2012 - Published: 22 August 2012

\begin{abstract}
To understand the different environment and morphology for heavy rainfall during 9-10 July 2007, over the Korean Peninsula, mesoscale convective systems (MCSs) that accompanied the Changma front in two different regions were investigated. The sub-synoptic conditions were analysed using mesoscale analysis data (MANAL), reanalysis data, weather charts and Multi-functional Transport Satellite (MTSAT-IR) data. Dual-Doppler radar observations were used to analyse the wind fields within the precipitation systems. During both the case periods, the surface lowpressure field intensified and moved northeastward along the Changma front. A low-level warm front gradually formed with an east-west orientation, and the cold front near the low pressure was aligned from northeast to southwest.

The northern convective systems (meso- $\alpha$-scale) were embedded within an area of stratiform cloud north of the warm front. The development of low-level pressure resulted in horizontal and vertical wind shear due to cyclonic circulation. The wind direction was apparently different across the warm front. In addition, the southeasterly flow (below $4 \mathrm{~km}$ ) played an important role in generating new convective cells behind the prevailing convective cell. Each isolated southern convective cell (meso- $\beta$-scale) moved along the line ahead of the cold front within the prefrontal warm sector. These convective cells developed when a strong southwesterly low-level jet (LLJ) intensified and moisture was deeply advected into the sloping frontal zone. A high equivalent potential temperature region transported warm moist air in a strong southwesterly flow, where the convectively unstable air led to updraft and downdraft with a strong reflectivity core.
\end{abstract}

Keywords. Meteorology and atmospheric dynamics (Mesoscale meteorology)

\section{Introduction}

Heavy rainfall over East Asia during the months of June and July is mainly stimulated by frontal precipitation systems elongated from west to east, known as Meiyu in China, Baiu in Japan and Changma in Korea. These frontal precipitation systems are usually accompanied by heavy rainfall and strong winds, which are among the most significant factors causative of natural disasters. In particular, during the summer, mesoscale convective systems (MCSs) along the front cause heavy rainfall in several East Asian countries, giving rise to flash floods and destruction.

The synoptic structure of the Meiyu/Baiu/Changma front is different from that of typical midlatitude fronts. The structures of the eastern (near Japan) and central (East China Sea) Meiyu/Baiu front resemble a typical midlatitude baroclinic front with strong vertical tilting toward a upper level cold core and a strong horizontal temperature gradient (Chen and Chang, 1980), whereas the western (Southern China and Yangtze River Basin) section resembles a semitropical disturbance with an equivalent barotropic warm core structure, a weak horizontal temperature gradient (Ding, 1992). Shinoda et al. (2005) described that the structures of moist layers were different over East China Sea and mainland China. Changma front in Korea has the character of the Baiu front in the southern part of Korea and also that of the Meiyu front in central Korea (Park et al., 1986). 


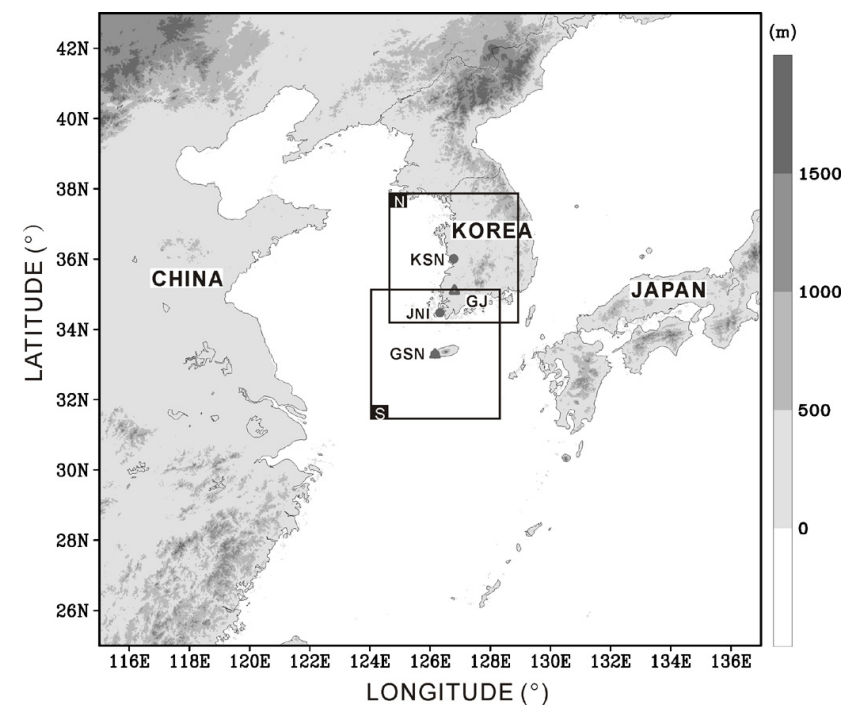

Fig. 1. Geographic map of Korean Peninsula in East Asia. Positions of Doppler radars (•) and upper-air sounding stations (GJ and GSN, $\Delta$ for 6-h interval) are shown. The boxes labeled "N" and "S" indicate the dual-Doppler radar analysis domains for KSN, JNI, and GSN radars.

Park et al. (1986) also pointed out that heavy precipitation associated with MCSs over the Korean Peninsula is related to a low-level jet (LLJ) transporting warm, moist air from southern China and a southeastward moving cold-core mid-tropospheric low from Siberia, both of which are responsible for the vigorous development of convections. Lee et al. (1998) suggested that MCSs were observed between the upper-level jet (ULJ) to the north and the LLJ to the south. Some of them are accompanied by mesoscale cyclones in the lower troposphere when they are fully developed (Akiyama, 1984a, b). Moreover, subsequent MCSs are intensified with the passage of typhoons and tropical storms (Kim and Lee, 2006).

In Meiyu/Baiu/Changma frontal zone, several types of MCSs are observed. Ninomiya and Akiyama (1992) suggested that heavy rainfall associated with the Baiu front is generated by meso- $\gamma$ - to meso- $\beta$-scale convective systems embedded in meso- $\alpha$-scale cloud cluster. The detailed structure of meso- $\gamma$ - or meso- $\beta$-scale convective system within meso- $\alpha$-scale cloud systems along the Baiu front was reported by Ishihara et al. (1995) and Takahashi et al. (1996). A meso- $\beta$-scale convective band was reportedly produced by low-level convergence under synoptic scale conditions (Sun and Lee, 2002). In addition, MCSs of the meso- $\alpha$ scale and cluster type were identified over the Korean Peninsula (Shin and Lee, 2005). Thus, frontal convective systems may be structurally (dynamically) different. Questions include the following: How environment can influence their structure and morphology of MCSs near the Changma front? And how do they form? In this study, we present the influence of environmental conditions on different types of MCSs in deter- mining their morphologies and comparison of their precipitation efficiency over the Korean region.

The mesoscale organisation of convection affects the kinematic structure and longevity of MCSs (LeMone et al., 1998). Momentum transport and the associated horizontal gradients in thermodynamic properties and wind shear on meso- $\gamma$ scales have been documented (Mueller et al., 1993; Thompson and Edwards, 2000). Shimizu et al. (2008) revealed that a formation of supercell-like storm in a moist environment processed relatively large convective available potential energy, strong vertical wind shear. Sharp-sheared environment was influenced on the formation of the mesoscale convective systems interaction of two individual convective storms (Ćurić et al., 2009). Moreover, MCS momentum transport, thermodynamic transport and rainfall affect the strength of the surface fluxes (LeMone, 1983), suggesting that the structure and evolution of MCSs are affected by vertical momentum transport and shear.

In order to elucidate the characteristics of the inner structure and flow in MCSs, high-resolution datasets are required. This study utilised Doppler radar, which provides datasets with high spatial and temporal resolutions of the internal structure of precipitation. In the past, dual-Doppler radar observations have provided in-depth information on structures of the meso- $\alpha$ and meso- $\beta$ scales, including their development in monsoon frontal systems (Yamada et al., 2003; Moteki et al., 2004; Geng et al., 2004). You et al. (2010) proved that deep warm-air advection (WAA) supports the maintenance of a convective system for a longer time and results in greater rain intensity, producing drops of larger sizes. However, no observational study using dual-Doppler radar datasets has been reported for convective cells accompanied by developing mesoscale processes in relation to the Changma front over Korea. By using dual-Doppler radar analysis and upper air sounding data, we investigate the organisation of convection in two different types of MCSs that accompanied the Changma front. In addition, we study the conditions of the synoptic and sub-synoptic environments that were favourable to such a development in the central and southern areas of the Korean Peninsula during 910 July 2007.

\section{Data and methodology}

\subsection{Observational data}

Radar data were obtained from operational S-band Doppler radars of the Korea Meteorological Administration (KMA) installed at Gosan $\left(\mathrm{GSN}, 33.29^{\circ} \mathrm{N}, 126.16^{\circ} \mathrm{E}\right)$, Jindo (JNI, $\left.34.47^{\circ} \mathrm{N}, 126.32^{\circ} \mathrm{E}\right)$, and Gunsan $\left(\mathrm{KSN}, 36.01^{\circ} \mathrm{N}\right.$, $126.79^{\circ} \mathrm{E}$ ). Upper-air sounding data over Gwangju (GJ, $35.11^{\circ} \mathrm{N}, 126.81^{\circ} \mathrm{E}$ ) and station GSN (same site as the radar) also were obtained from the KMA. A map depicting the radar and upper-air sounding locations are shown in Fig. 1. Surface 

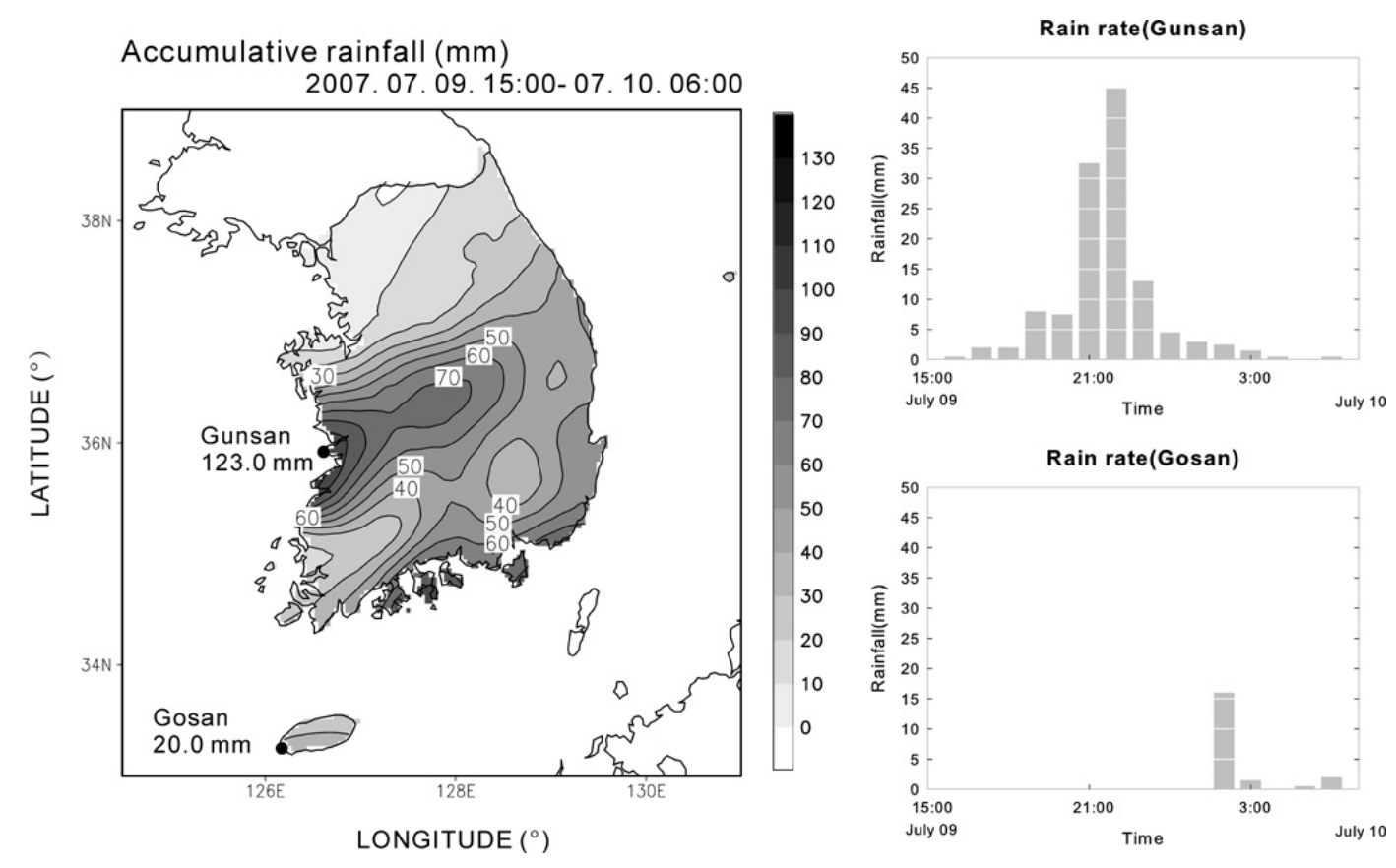

Fig. 2. The 15-h accumulated rainfall amounts over Korea from 15:00 LST, 9 July to 06:00 LST, 10 July 2007 (left). Temporal variation of rainfall at Gunsan and Gosan at 1-h intervals (right).

meteorological observations were received from collocated sites of the Automatic Weather System (AWS) operated by the KMA. Hourly infrared images from the Multi-functional Transport Satellite (MTSAT-IR) obtained from the Weather Satellite Image Archive, Kochi University, were used to examine cloud distribution. These images have a grid spacing of $0.05^{\circ}$ along both longitudinal and latitudinal directions. In addition, manually interpreted surface weather maps in conjunction with the Japan Meteorological Agency (JMA) mesoscale analysis (MANAL) data (3-hourly fine pressure data at a $10-\mathrm{km}$ horizontal resolution at 20 pressure levels) were used for mesoscale analysis and diagnosis of the development of the MCSs.

\subsection{Analysis method}

\subsubsection{Three-dimensional transformation of radar data}

Doppler radars, covering a radius of $250 \mathrm{~km}$ in the central and southern areas of the Korean Peninsula, record volume scans of reflectivity and Doppler velocity every $10 \mathrm{~min}$. The sampling resolution of the radar data is $250 \mathrm{~m}$ in the radial direction and $1.0^{\circ}$ in the azimuthal direction. The GSN, KSN and JNI radars make volume scans that consist of 15 or 12 elevation angles.

The radar data are interpolated on Cartesian grids using a Cressman (1959) weighting scheme. Therefore, the data are transformed from spherical coordinates to Cartesian coordinates. The interpolated mean Doppler velocities $\left(\overline{V_{1}}, \overline{V_{2}}\right)$ and the reflectivity $(\bar{Z})$ are given by

$\bar{V}_{1(2)} \bar{Z}=\sum_{i=1}^{N}\left(V_{i, 1(2)} Z_{i}\right) / \sum_{i=1}^{N} W_{i}$

$W_{i}=\frac{R_{i}^{2}-D_{i}^{2}}{R_{i}^{2}+D_{i}^{2}}$

where $N$ is the total number of data points within the averaging volume, $W_{i}$ is the Cressman filter, $R_{i}$ is the influence radius, and $D_{i}$ is the distance grid of point.

\subsubsection{Three-dimensional variational method}

Vertical velocity is usually obtained by vertical integration of the mass continuity equation. In this method, after the removal of noise and the correction of folded Doppler velocities, ambiguity arises from boundary condition errors due to data voids in the lower or upper regions of the storm as observed by Doppler radar (Ray et al., 1980). To avoid this bias in wind field retrievals, in this study, we used the variational method proposed by Gao et al. (1999). The parameter settings for the analysis were constrained in accordance with Gao et al. (1999). The variational method considers the mass continuity equation as a weak constraint, hence, the explicit setting of boundary conditions for the vertical velocity and the explicit integration of the mass continuity equation are avoided, thereby reducing the error accumulated in the vertical velocity. 


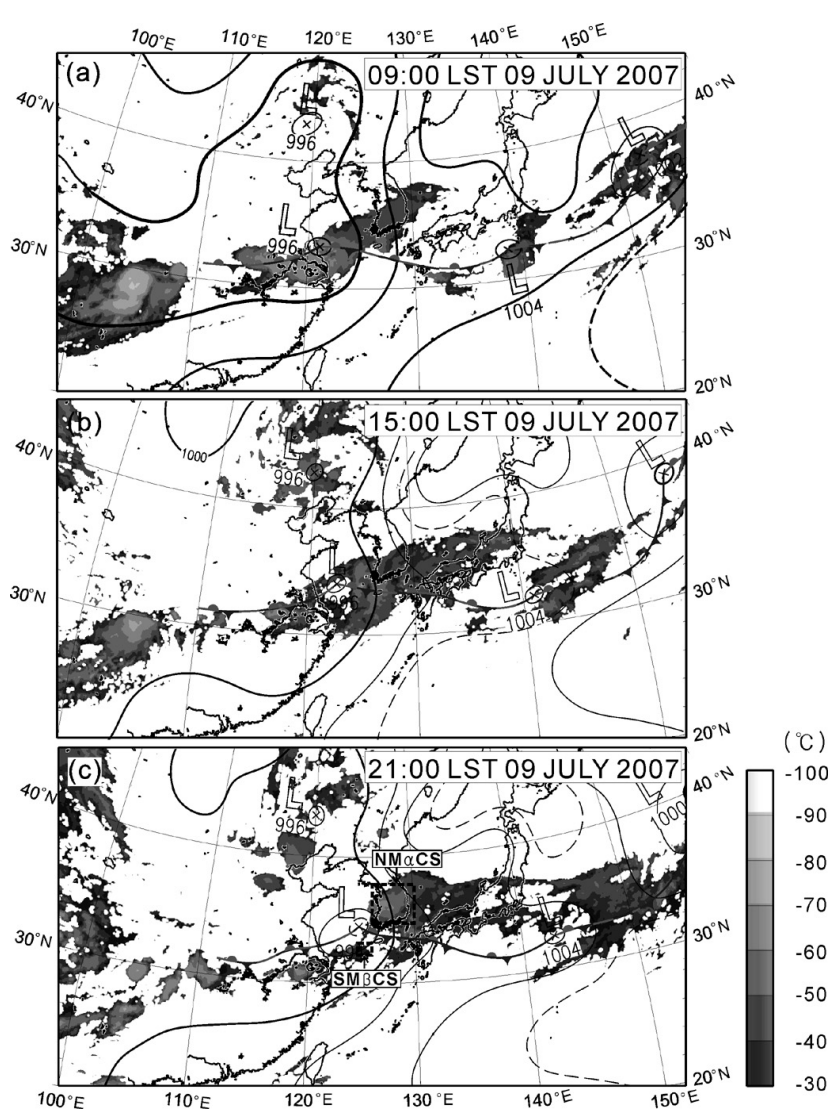

Fig. 3. Surface weather maps with superimposed MTSAT-IR images at (a) 09:00 LST, (b) 15:00 LST, and (c) 21:00 LST, 9 July 2007. The echo areas in the northern and southern boxes of part (c) indicate $\mathrm{NM} \alpha \mathrm{CS}$ and $\mathrm{SM} \beta \mathrm{CS}$.

Volume scans from the KSN and JNI radars were used to retrieve three-dimensional reflectivity and wind fields in the domain labeled "N", while volume scans from the GSN and JNI radars were used to retrieve those in the domain labeled "S", as shown in Fig. 1.

\section{Results and discussion}

Different types of MCSs passed over Korea from 15:00 LST, 9 July to 06:00 LST, 10 July 2007 (LST $=\mathrm{UTC}+9 \mathrm{~h})$. In this section, we investigate the structure and evolution of the Changma front with surface low pressure. Development processes for northern meso- $\alpha$ scale convective system (hereafter called NM $\alpha \mathrm{CS}$ ) and southern meso- $\beta$ scale convective system (hereafter called SM $\beta C S$ ) were analysed using data from mesoscale analysis and dual-Doppler radar.

\subsection{Precipitation distribution and synoptic scale overview}

Figure 2 shows the 15-h accumulated rainfall amounts over Korea and time series of the rain rate from 15:00 LST, 9 July to 06:00 LST, 10 July at the Gunsan (upper right) and Gosan (lower right) stations, respectively.

The locally different rainfall amounts occurred over the central and southern areas of the Korean Peninsula. The NM $\alpha$ CS passed over the central area from 15:00 LST, 9 July to 00:00 LST, 10 July. Following NM $\alpha \mathrm{CS}, \mathrm{SM} \beta \mathrm{CS}$ moved over the southern area from 22:00 LST, 9 July to 06:00 LST, 10 July.

The rainfall distribution indicates that in $\mathrm{NM} \alpha \mathrm{CS}$, the widespread heavy rainfall over the central and southern areas. However, in $\mathrm{SM} \beta \mathrm{CS}$, rainfall amount recorded relatively narrow area over southern area. The accumulated rainfall amounts (maximum rainfall intensity) were $123.0 \mathrm{~mm}$ $\left(45.0 \mathrm{~mm} \mathrm{~h}^{-1}\right)$ and $20.0 \mathrm{~mm}\left(16.0 \mathrm{~mm} \mathrm{~h}^{-1}\right)$ at Gunsan and Gosan, respectively. The amount and rate of rainfall were small in $\mathrm{SM} \beta C \mathrm{CS}$, since the convective cells had relatively fast moving speed.

Figure 3 shows time series of the surface weather and cloud-top temperature from 09:00 LST to 21:00 LST on 9 July. This reveals the presence of an east-west-oriented Changma front that extended from China to Japan. The warm front at the low level was oriented from southeast to west, and the cold front near the low pressure was aligned from northeast to southwest (see weather maps in Fig. 3). With the intensification of surface low pressure, the front propagated northeastward and appeared in southeastern China with high cloud area $\left(\mathrm{TBB} \leq-60^{\circ} \mathrm{C}\right)$ as shown in Fig. 3a. By 15:00 LST on 9 July, the high cloud area became weak across the ocean. However, a trough formed over the southern Korean Peninsula, resulting in stratiform cloud cover over the central Korean Peninsula. After $6 \mathrm{~h}$, the surface low pressure intensified over the oceanic region and the high cloud area passed over the central and southern areas of the Korean Peninsula (Fig. 3c). On moving inland, the intensified $\mathrm{NM} \alpha \mathrm{CS}$ organised into a circular shape north of a warm front. Widespread convection outbreaks were observed and the cloud top temperature was found to reach $-60^{\circ} \mathrm{C}\left(34^{\circ} \mathrm{N}\right.$, $\left.127^{\circ}-130^{\circ} \mathrm{E}\right) . \mathrm{SM} \beta \mathrm{CS}$ commenced ahead of the cold front over the ocean $\left(33^{\circ} \mathrm{N}, 123^{\circ}-126^{\circ} \mathrm{E}\right)$. Convection had broken out over the southwestern Korean Peninsula and gradually formed a band shape.

\subsection{Evolution and structure of Changma front}

\subsubsection{Sub-synoptic environment around front}

In this section, the sub-synoptic environment and structure of the front on 9 July 2007, are further examined using JMA MANAL data at resolutions of $10 \mathrm{~km}$ and $3 \mathrm{~h}$. Figure 4 shows the geopotential heights, winds and divergence around the front under the sub-synoptic conditions at surface $(1000 \mathrm{hPa}$ ). The low-pressure area (about $600 \mathrm{~km}$ in diameter) intensified and moved northeastward along the front. The horizontal gradient of geopotential height also intensified in association with the deepening low. An area surrounding the 
surface low pressure was characterised by cyclonic circulation. The warm front was located within the wind-shift line, with southeasterly and southwesterly winds to the north and south, respectively. However, strong southwesterly flow of about $20 \mathrm{~m} \mathrm{~s}^{-1}$ prevailed around the cold front.

In accordance with enhanced cyclonic circulation, the divergence field observed at surface indicates a weak convergence $\left(3 \times 10^{-5} \mathrm{~s}^{-1}\right)$ aligned with the warm front at 21:00 LST on 9 July. Convergence began to intensify along the front, with the areas in north of the warm front. At 00:00 LST on $10 \mathrm{July,} \mathrm{this} \mathrm{stronger} \mathrm{convergence} \mathrm{existed}$ over a broad area north of the warm front. It is noted that widespread convergence played a role in the broad area of convection (Fig. 4a). In addition, a weak and narrow convergence $\left(2 \times 10^{-5} \mathrm{~s}^{-1}\right)$ was also observed to be forming along the cold front. This convergence apparently organised into bands oriented nearly parallel with the cold front at 00:00 LST on 10 July (Fig. 4b).

\subsubsection{Analysis of vertical structure of front}

The vertical cross-sections along line $\mathrm{A}-\mathrm{A}^{\prime}$ (from $124^{\circ} \mathrm{E}$, $41^{\circ} \mathrm{N}$ to $129^{\circ} \mathrm{E}, 33^{\circ} \mathrm{N}$ ) and line $\mathrm{B}-\mathrm{B}^{\prime}$ (from $120^{\circ} \mathrm{E}, 36^{\circ} \mathrm{N}$ to $125^{\circ} \mathrm{E}, 29^{\circ} \mathrm{N}$ ), through the developed convective cells over the central and southern areas of the Korean Peninsula at 00:00 LST on 10 July, are shown in Figs. 5 and 6.

Figure 5 shows a vertical cross-section across the warm front, east-southeasterly flows prevailed above the frontal zone, which induced convergence within the zone, most evidently at low-to-middle levels (Fig. 5b). In response to the convergence, the frontal potential temperature $(\theta)$ gradient increased. Associated with an increase in prefrontal eastsoutheasterly flow, the cross-frontal horizontal wind shear below $500 \mathrm{hPa}$ also strengthened, consistent with the response to low-level frontogenesis based on semi geostrophic theory (e.g., Shapiro and Keyser, 1990; Bluestein, 1993, his Sect. 2.5).

In the vertical cross-section across the cold front, the frontal zone based on $\theta$ distribution with height was relatively steep. A strong and consistent west-southwesterly wind existed ahead of the cold front associated with LLJ and the ULJ near $200 \mathrm{hPa}$ (Fig. 6a). A weak convergence zone appeared from $900 \mathrm{hPa}$ to $500 \mathrm{hPa}$ toward the northeast, corresponding with the sloping frontal zone (Fig. 6b). Another convergence zone existed at the leading edge of the strong southwesterly wind area $\left(\geq 20 \mathrm{~m} \mathrm{~s}^{-1}\right)$ near $700 \mathrm{hPa}$. Moisture was largely and deeply advected into the sloping frontal zone. Shinoda and Uyeda (2002) documented shallow convective clouds moisten the middle troposphere by evaporation when they disappear. The evaporation from the wet environment provides a supply of moisture which considerably increases the amount of water in the shallow planetary boundary layer (PBL) that develops above it, as can be seen from the vertical cross-section $\left(\mathrm{B}-\mathrm{B}^{\prime}\right)$ of mixing ratio presented in Fig. 6b. Furthermore, moisture is advected by southwesterly flow, which strongly converges toward ocean. Their ability to transport moist, warm air to higher elevations increases the amount of water that can be condensed and precipitated.

\subsection{Effect of moisture advection associated with LLJ}

To examine the development of the LLJ near the lowpressure area, we investigate the role of ageostrophic wind. Figure $7 \mathrm{a}$ shows at $850 \mathrm{hPa}$ wind speed and ageostrophic wind obtained by subtracting the geostrophic wind from the actual wind. As the geopotential height gradient near the surface low pressure increased, the associated fall in geopotential height was apparently responsible for the generation of ageostrophic winds to the east-southeast across the LLJ core exit. In this case, the ageostrophic winds that prevailed across the jet peaked at roughly $20 \mathrm{~m} \mathrm{~s}^{-1}$, while the Coriolis parameter at $34^{\circ} \mathrm{N}$ is roughly $8 \times 10^{-5} \mathrm{~s}^{-1}$. Therefore, the Coriolis torque of the ageostrophic flow would produce a wind speed increase to about $20.8 \mathrm{~m} \mathrm{~s}^{-1}$. This suggests that an LLJ was formed and greatly intensified (Chen et al., 2006). In other words, the ageostrophic wind helped to maintain or accelerate the LLJ. In this case, a strong wind occurred ahead of the cold front, with local maxima of $\geq 27 \mathrm{~m} \mathrm{~s}^{-1}$ (Fig. 7a), clearly exceeding the criterion of $12.5 \mathrm{~m} \mathrm{~s}^{-1}$ for an LLJ (Chen and Yu, 1988).

The LLJ transports warm moist air from low latitude at low levels to generate convective instability and lower the level of free convection (Chen, 1983). In this case, the strong LLJ transported warm moist air mainly at $850 \mathrm{hPa}$, especially ahead of the cold front. Moisture Transport Vectors (MTVs), computed as the product of the wind vector $(\boldsymbol{V})$ and mixing ratio $(q)$ at $850 \mathrm{hPa}$, are shown in Fig. 7b. The MTVs reveal a strong transport of water vapour along the cold front. It noted that moisture significantly advected over southwestern Korean Peninsula. MTVs shift line located at the warm front. Another useful parameter is the Moisture Flux Convergence (MFC) at $850 \mathrm{hPa}$, computed as $-\nabla \cdot q \boldsymbol{V}$ with the unit of $10^{-4} \mathrm{~s}^{-1} \mathrm{~g} \mathrm{~kg}^{-1}$. Over the cold front, a narrow band of weak MFC $\left(1.5 \times 10^{-4} \mathrm{~s}^{-1} \mathrm{~g} \mathrm{~kg}^{-1}\right)$ was simulated. This is indicative of destabilization and was an important factor as a linear rain band. A broad area of strong MFC $\left(6 \times 10^{-4} \mathrm{~s}^{-1} \mathrm{~g} \mathrm{~kg}^{-1}\right)$ formed behind the warm front.

Figure $7 \mathrm{c}$ shows the fields of equivalent potential temperature $\left(\theta_{\mathrm{e}}\right)$ at $900 \mathrm{hPa}$ and temperature at $850 \mathrm{hPa}$. SM $\beta C$ C was located with the equivalent potential temperature over $350 \mathrm{~K}$ in the southwestern Korean Peninsula where the mixing ratio was about $15 \mathrm{~g} \mathrm{~kg}^{-1}$ at $850 \mathrm{hPa}$. At this time, a strong $\theta_{\mathrm{e}}$ associated with a tongue of warm and moist air into a convectively unstable atmosphere was found over the core of the LLJ and downstream, the genesis of the $\operatorname{SM} \beta C S$ at $\left(33^{\circ} \mathrm{N}\right.$, $126.5^{\circ} \mathrm{E}$ ) reached a maximum (Fig. $11 \mathrm{~b}$ ). In addition, the thermal contrast across the cold front at this time was $4-5^{\circ} \mathrm{C}$. The Changma front had a larger baroclinicity along the cold front. 


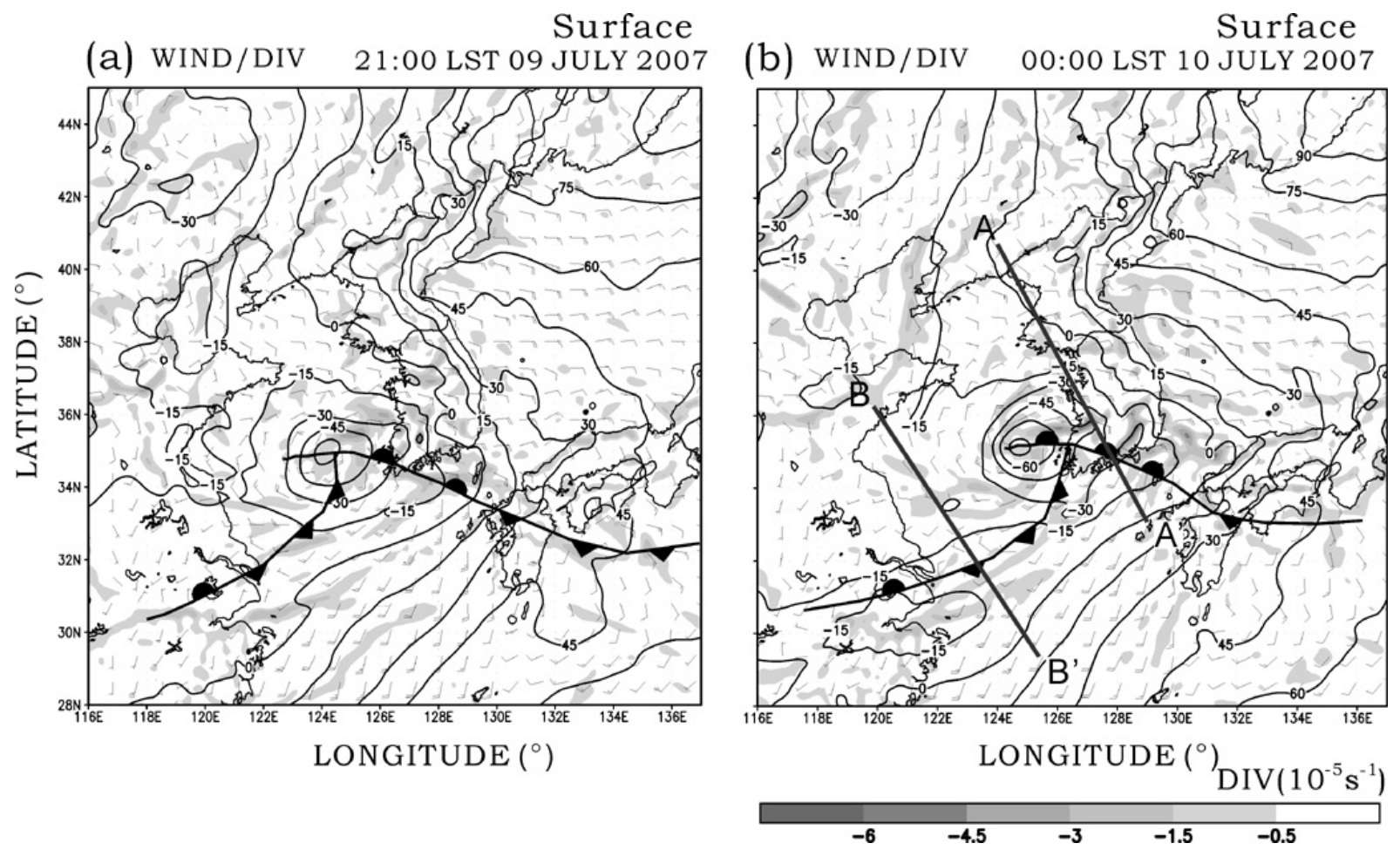

Fig. 4. Mesoscale analysis of divergence $\left(10^{-5} \mathrm{~s}^{-1}\right.$, shaded), geopotential height (contoured every 5 gpm), and horizontal wind (m s $\mathrm{s}^{-1}$, barbs at surface for (a) 21:00 LST, 9 July and (b) 00:00 LST, 10 July 2007. For winds, full (half) barbs denote $5 \mathrm{~m} \mathrm{~s}^{-1}\left(2.5 \mathrm{~m} \mathrm{~s}^{-1}\right)$. The location of the front at each time is superimposed. The lines $\mathrm{A}-\mathrm{A}^{\prime}$ and $\mathrm{B}-\mathrm{B}^{\prime}$ are used to construct Figs. 5 and 6.

(a) $\Theta /$ Wind A-A'Vertical Cross Section

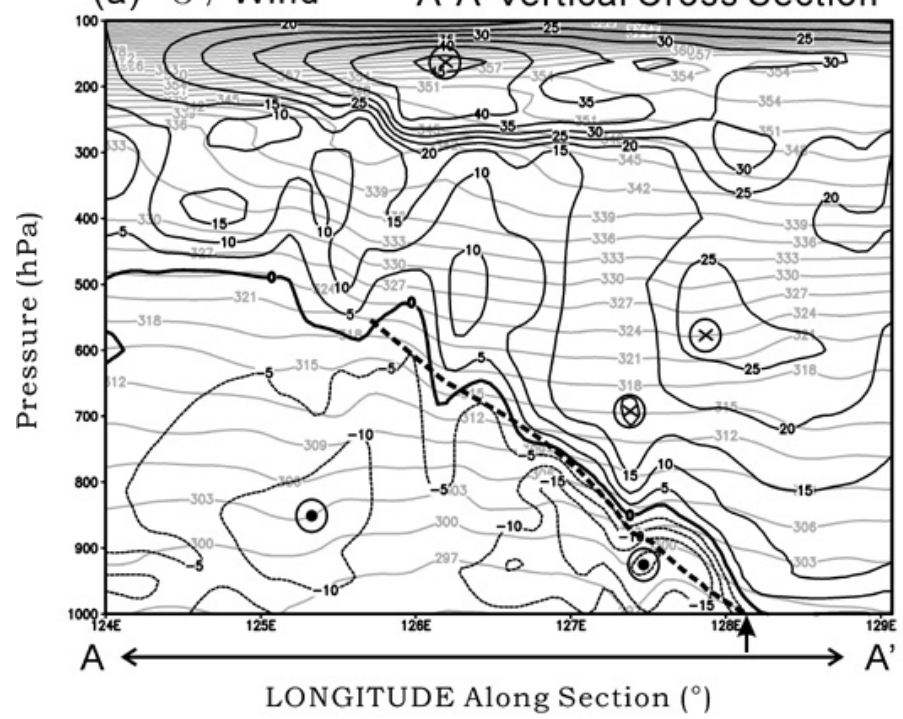

(b) Q / Div

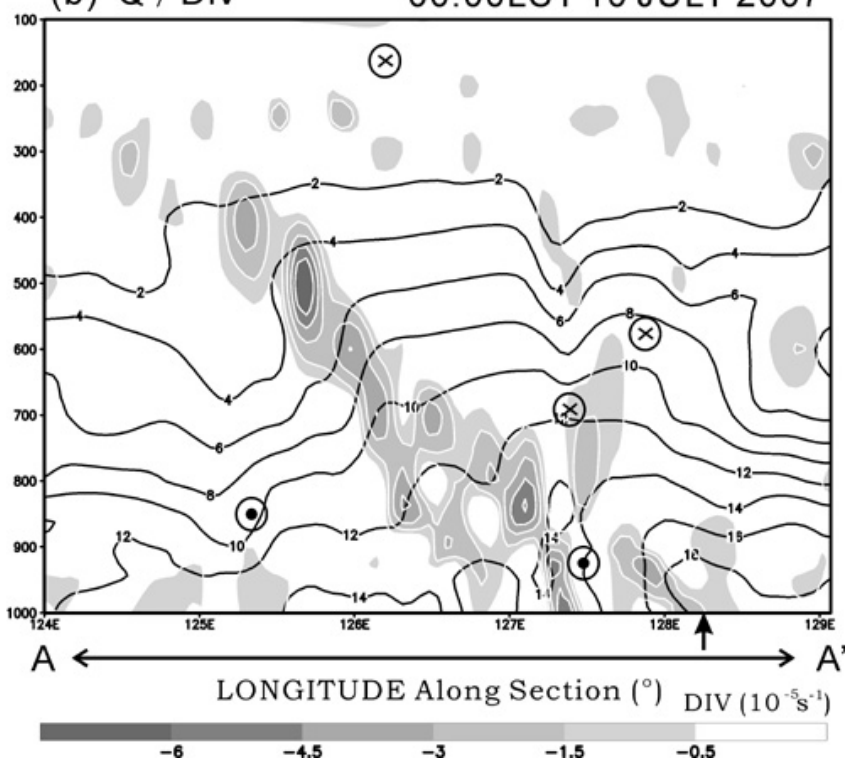

Fig. 5. Vertical cross-sections from $124^{\circ} \mathrm{E}, 41^{\circ} \mathrm{N}$ to $129^{\circ} \mathrm{E}, 33^{\circ} \mathrm{N}$ (line $\mathrm{A}-\mathrm{A}^{\prime}$ in Fig. $4 \mathrm{~b}$ ): (a) potential temperature $\theta$ (K, grey line) and horizontal wind component normal to section plane $\left(\mathrm{m} \mathrm{s}^{-1}\right.$, solid for positive, dashed for negative and thickened for zero); and (b) divergence $\left(10^{-5} \mathrm{~s}^{-1}\right.$, shaded) and mixing ratio $q\left(\mathrm{~g} \mathrm{~kg}^{-1}\right.$, contoured) between $1000 \mathrm{hPa}$ and $100 \mathrm{hPa}$. The arrows represent the location of the surface front. The thick dotted lines indicate the frontal zone. Crossed circles $(\otimes)$ denote the positive wind direction into the page, and dotted circles $(\odot)$ denote the negative wind direction out of the page. 
(a) $\Theta /$ Wind

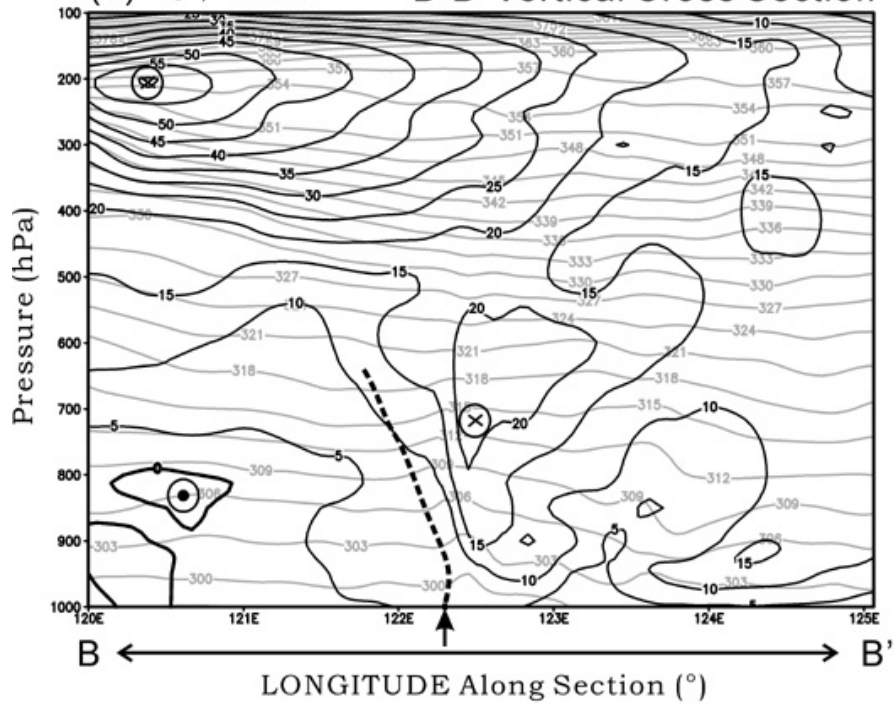

(b) Q / Div

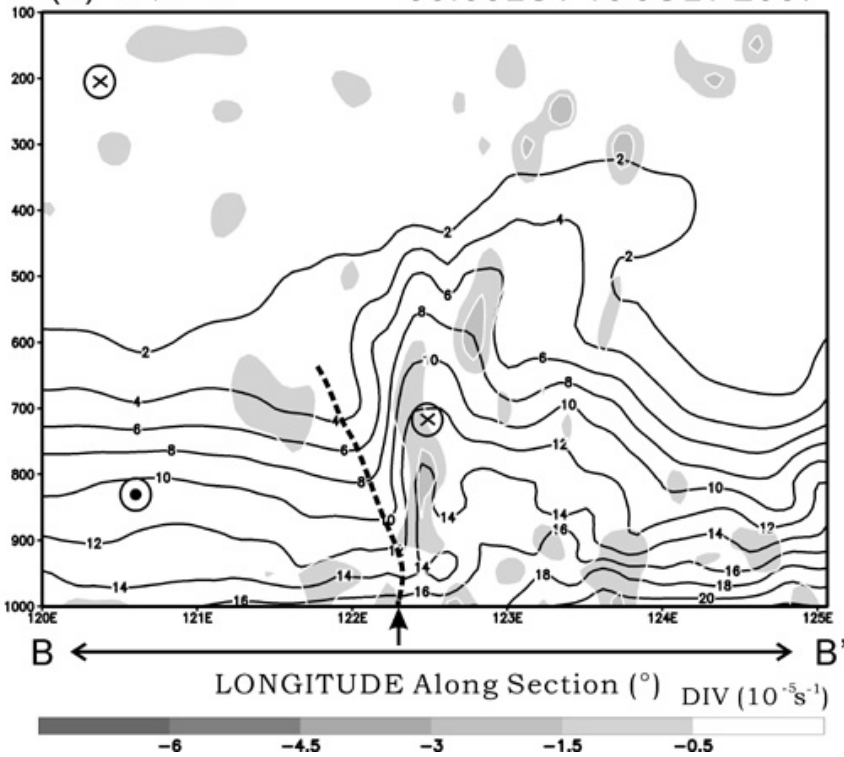

Fig. 6. Same as Fig. 5 except for line B-B' (from $120^{\circ}$ E, $36^{\circ} \mathrm{N}$ to $125^{\circ}$ E, $29^{\circ} \mathrm{N}$ ) in Fig. $4 \mathrm{~b}$.

\subsection{Precipitation efficiency}

Precipitation efficiency (Pe) for $\mathrm{NM} \alpha \mathrm{CS}$ and $\mathrm{SM} \beta \mathrm{CS}$ over central and southern Korea are calculated. Pe is the ratio (\%) of measurable precipitation to moisture transport into an area. This study comprised areas (area 1 and 2) on the contrasting precipitation and varying exposures to water vapour transport (Fig. 7c). The time period depended from NM $\alpha \mathrm{CS}$ (15:00-24:00 LST, 9 July) and SM $\beta$ CS (00:00-06:00 LST, 10 July). Precipitation corresponding to each station was calculated by summation of hourly precipitation. In addition, water vapour was calculated by MANAL data, summing the contribution from $500 \mathrm{hPa}$ above the surface for which specific humidity and wind speed were available.

The results indicated the Pe of 43.4 and $12.5 \%$ when calculated over area 1 and 2 . The efficiency in area 1 has higher value than that estimated over area 2. A high Pe would have large impacts by increasing the available amount of precipitation reaching the surface. This case study provided a relatively higher Pe in area 1, indicating $\mathrm{NM} \alpha \mathrm{CS}$ had large precipitation and less available moisture compared to area 2. A low Pe showed that large moisture was being transported into the region. The entire region in area 2 showed consistently high relative humidity $\geq 80 \%$ in lower troposphere. Thus, the Pe for NM $\alpha$ CS and SM $\beta$ CS showed an obvious contrast between area 1 and 2 .

There were a few articles available in the literature that can be used for comparison of these Pe results. McBean and Stewart (1991) estimated that the Pe was very high (near $70 \%$ ) within an occluded system over the North Pacific Ocean. Houze and Cheng (1981) showed the Pe of a warm frontal precipitation band to be even higher (70-90\%) over midlatitude. Carbone (1982) estimated the Pe of $77 \%$ for a narrow cold frontal band. However, the Pe values obtained here are lower than that reported over other studies, high measurable precipitation amount and low Pe means that even though precipitation is abundant there is a great deal of moisture in the air that is not being utilised than the others.

\subsection{Wind and thermodynamic environment by upper- air sounding}

The wind and thermodynamic structure of both convective systems (NM $\alpha \mathrm{CS}$ and $\mathrm{SM} \beta \mathrm{CS})$ are described using upperair sounding data. The location of sounding station GJ was about $100 \mathrm{~km}$ south of $\mathrm{NM} \alpha \mathrm{CS}$, and $\mathrm{SM} \beta \mathrm{CS}$ passed directly over station GSN.

The hodograph corresponding to Fig. 8a shows vertical wind shear through deep layers and strongly veering with height, accompanied by warm advection from the surface to $5 \mathrm{~km}$. After the $\mathrm{NM} \alpha \mathrm{CS}$ passed over the observation site at 15:00 LST on 9 July, the wind shear had significantly increased. The GJ sounding at 21:00 LST yielded a bulk shear (BS) of $3.6 \times 10^{-3} \mathrm{~s}^{-1}$ for $0-6 \mathrm{~km}$. The shear values were comparable to the range found for the broken areal type (Bluestein and Jain, 1985). Supercell-like storm processed the vertical wind shear of $4.2 \times 10^{-3} \mathrm{~s}^{-1}$ from surface to $5 \mathrm{~km}$ in a moist environment (Shimizu et al., 2008). However, the BS in the GSN sounding was only slightly greater $(1.9 \times$ $10^{-3} \mathrm{~s}^{-1}$ for $0-6 \mathrm{~km}$ ) while SM $\beta$ CS was passed (Fig. $8 \mathrm{~b}$ ).

In the time-height cross-sections of the horizontal winds, $\theta_{\mathrm{e}}$ and $q$ increased at 3-6 km during 15:00-21:00 LST, 9 July (Fig. 9a), which suggests that moisture was able to rise above the warm front. Synoptic conditions such as WAA and an 

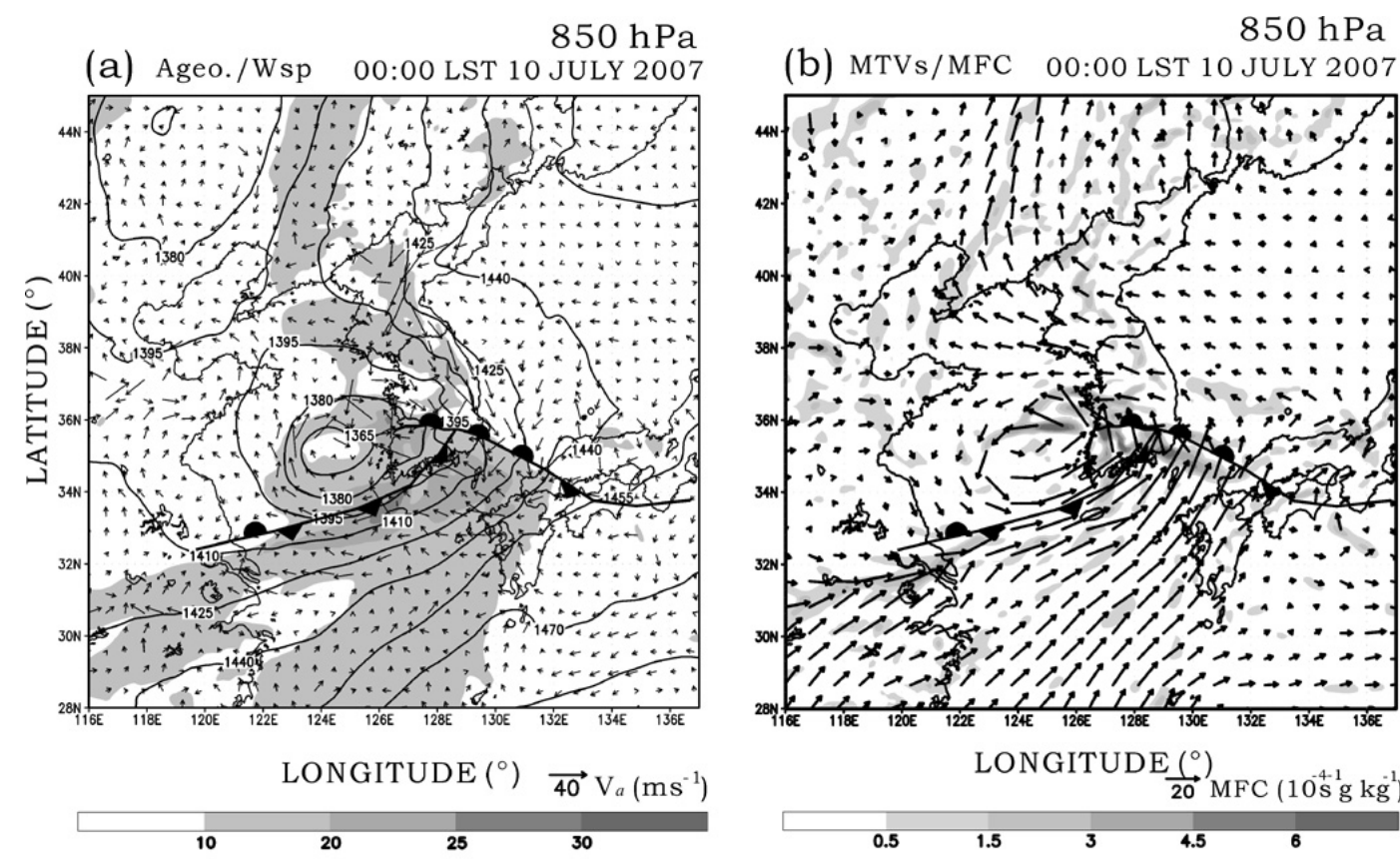

(b) MTVs/MFC 00:00 LST 10 JULY 2007
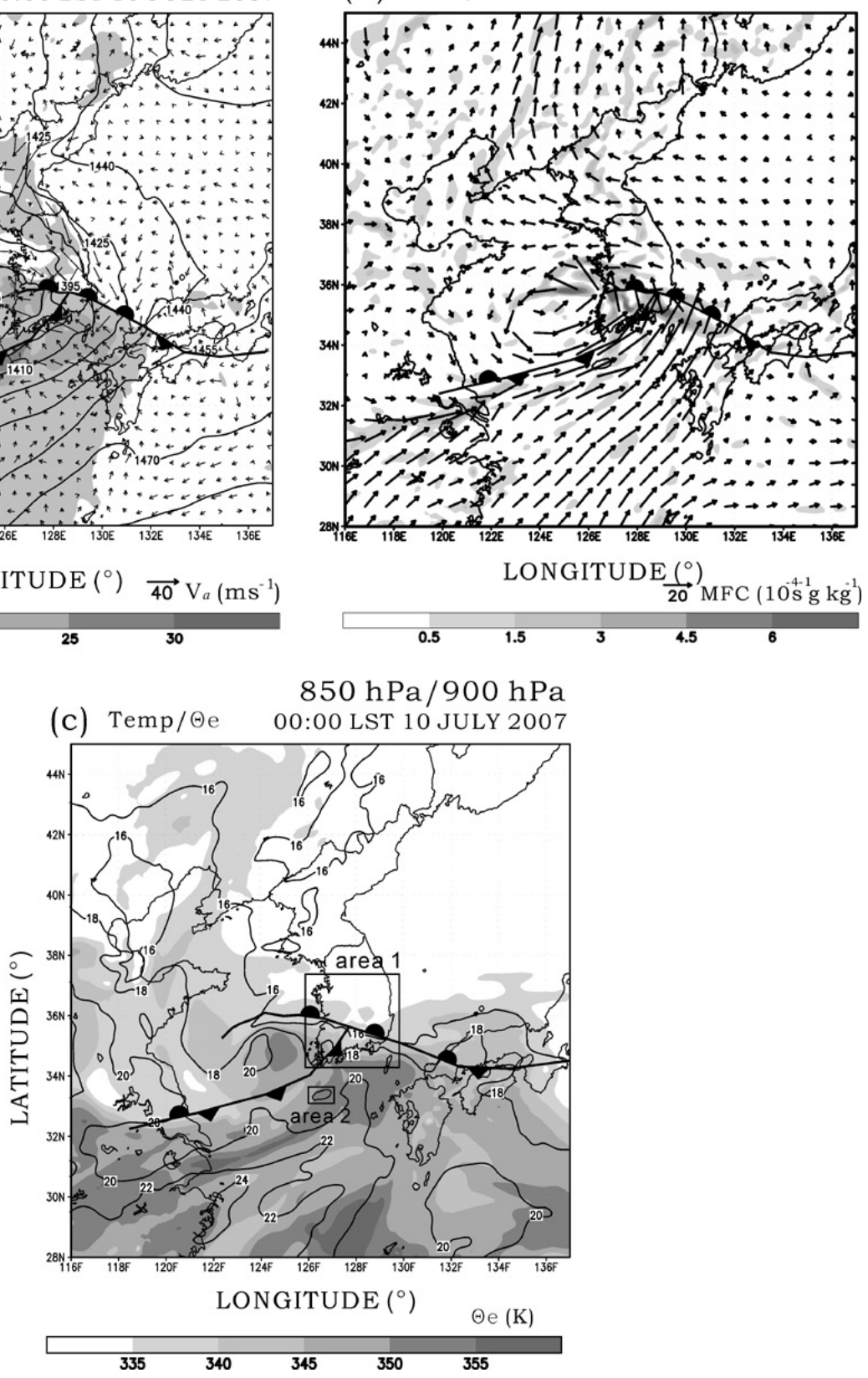

Fig. 7. Mesoscale analysis for 00:00 LST, 10 July 2007: (a) geopotential height (contoured every 5 gpm), horizontal wind speed ( $\mathrm{m} \mathrm{s}^{-1}$, shaded) and ageostrophic winds ( $\mathrm{m} \mathrm{s}^{-1}$, arrows); (b) moisture transport vectors $\left(\mathrm{m} \mathrm{s}^{-1} \mathrm{~g} \mathrm{~kg}^{-1}\right.$, arrows), moisture flux convergence $\left(10^{-4} \mathrm{~s}^{-1} \mathrm{~g} \mathrm{~kg}^{-1}\right.$, shaded) at $850 \mathrm{hPa}$; and (c) equivalent potential temperature $\theta_{\mathrm{e}}(\mathrm{K}$, shaded) at $900 \mathrm{hPa}$, and temperature (contoured every $\left.2{ }^{\circ} \mathrm{C}\right)$ at $850 \mathrm{hPa}$.

LLJ were favourable for deep convection, and strong lowlevel vertical shear related to $\mathrm{NM} \alpha \mathrm{CS}$ was also conducive to destabilization of convective systems. Figure $9 \mathrm{~b}$ shows that the horizontal winds, $\theta_{\mathrm{e}}$ and $q$ below $3 \mathrm{~km}$ clearly indicate $q\left(\geq 20 \mathrm{~g} \mathrm{~kg}^{-1}\right)$ and $\theta_{\mathrm{e}}(\geq 350 \mathrm{~K})$ from 15:00 LST, 9 July to 03:00 LST, 10 July. The southwesterly wind $\left(\geq 20 \mathrm{~m} \mathrm{~s}^{-1}\right)$ related to the LLJ strengthened throughout the entire tro- posphere, most significantly at $0-3 \mathrm{~km}$. The moisture was strongly advected below $850 \mathrm{hPa}$ before the passage of the $\mathrm{SM} \beta C \mathrm{CS}$, the convection was the likely response of nearly saturated parcels ascending through convectively unstable layer $\left(\partial \theta_{\mathrm{e}} / \partial z<0\right)$ from $850 \mathrm{hPa}$ to $600 \mathrm{hPa}$. 

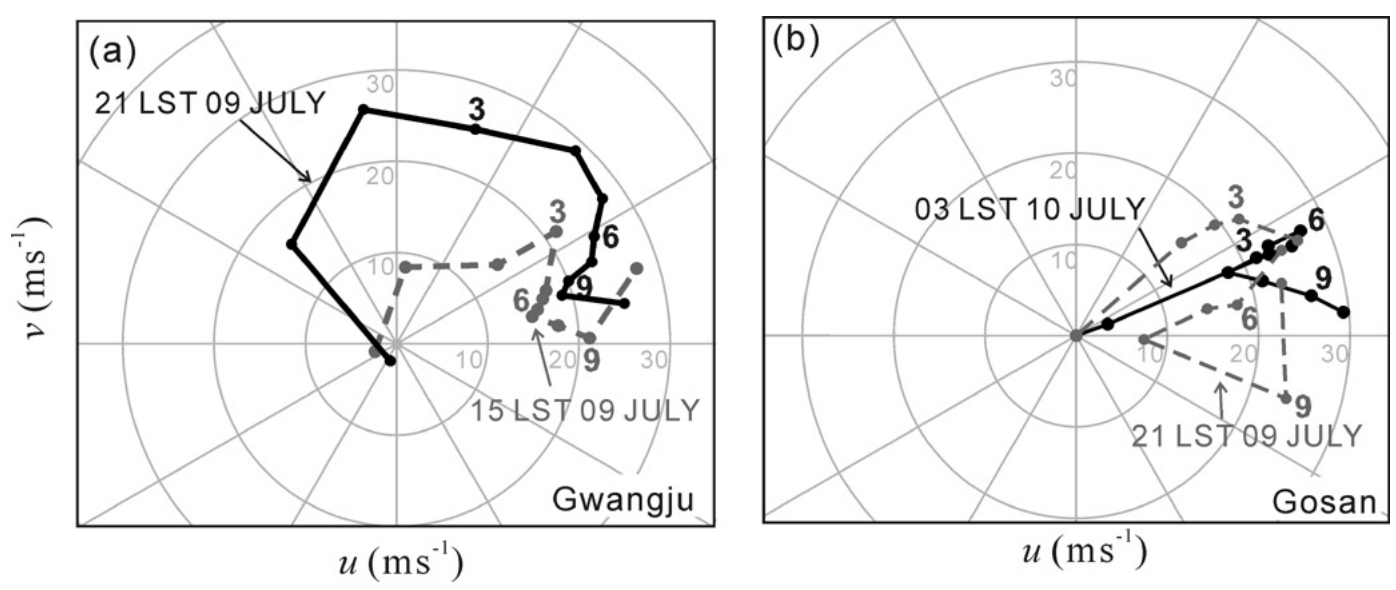

Fig. 8. Hodographs of soundings taken at (a) Gwangju and (b) Gosan (both shown in Fig. 1) at 15:00 LST, 9 July and 03:00 LST, 10 July 2007, respectively. The dot indicates height (dotted every $1 \mathrm{~km})$.

(a) Gwangju 0709 0900 LST $0710 \_0900$ LST

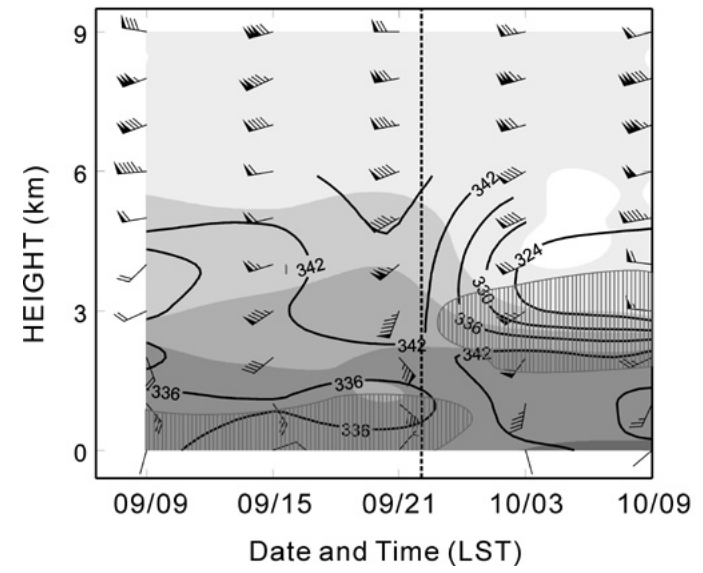

(b) Gosan 0709_1500 LST 0710_1500 LST

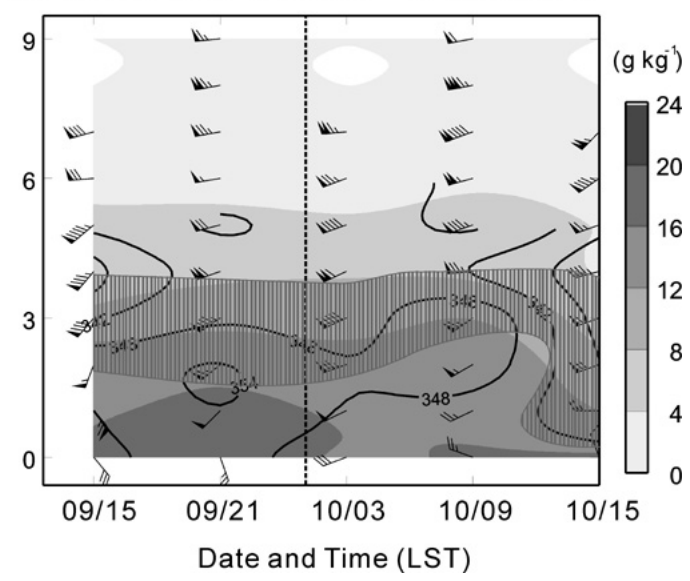

Fig. 9. Time height cross-section of equivalent potential temperature $\theta_{\mathrm{e}}$ (contoured every $6 \mathrm{~K}$ ), mixing ratio $q$ ( $\mathrm{g} \mathrm{kg}^{-1}$, shaded), and horizontal wind (knot, barbs) of soundings taken at (a) Gwangju and (b) Gosan. The shaded area indicates unstable layer. The dotted line is passage time of the NM $\alpha \mathrm{CS}$ and SM $\beta \mathrm{CS}$, near 22:00 LST, 9 July and 01:00 LST, 10 July, respectively. For winds, full (half) barbs denote $5 \mathrm{~m} \mathrm{~s}{ }^{-1}$ $\left(2.5 \mathrm{~m} \mathrm{~s}^{-1}\right)$.

\subsection{Three-dimensional structure and development pro- cesses of convective systems}

As mentioned in the discussion of the precipitation distribution pattern, two different convective systems related to the Changma front occurred over the central and southern areas of the Korean Peninsula. The inner structure and flows of $\mathrm{NM} \alpha \mathrm{CS}$ and $\mathrm{SM} \beta \mathrm{CS}$ will now be described.

Figure 10 shows the time series of horizontal reflectivity at $2 \mathrm{~km}$ above sea level (a.s.l.) from the KSN Doppler radar. The time interval was 2-h, from 18:30 LST to 22:30 LST on 9 July. The NM $\alpha \mathrm{CS}$ formed and developed with an extent of around $240 \mathrm{~km}$ near the central Korean Peninsula. The convective cells ( $\geq 35 \mathrm{dBZ}$ ) in NM $\alpha \mathrm{CS}$ were within an area of stratiform cloud north of the warm front. As shown in Fig. 10a, stratiform cloud cover was widespread over the cen- tral area of the Korean Peninsula during the early stage. The developed convective cells moved over the western coastal region within the stratiform cloud. The small convective cells slowly merged to generate large convective systems near the inland area. The shape of the convective area became linear at 20:30 LST (Fig. 10b). The strongest reflectivity value was $40 \mathrm{dBZ}$, over the western coastal region. $\mathrm{NM} \alpha \mathrm{CS}$ had horizontal dimensions of $240 \mathrm{~km} \times 65 \mathrm{~km}$ and propagated northeastward. The individual cells had slowed down to a mean speed of about $14.4 \mathrm{~m} \mathrm{~s}^{-1}$. The sequential and intensive convective system had a relatively long lifetime of $4-\mathrm{h}$, from 18:30 LST to 22:30 LST.

The $\mathrm{SM} \beta \mathrm{CS}$ formed and developed near the southern area of the Korean Peninsula from 9 July to 10 July 2007. Figure 11 shows time series of horizontal reflectivity at $2 \mathrm{~km}$ a.s.l. from the GSN Doppler radar (shown in Fig. 1) 
(a) 18:30 LST 09 JULY 2007 2km CAPPI

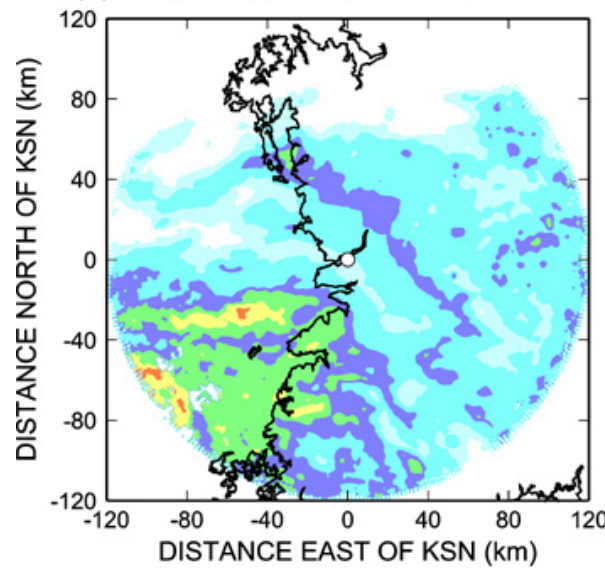

(b) 20:30 LST 09 JULY 2007 2km CAPPI

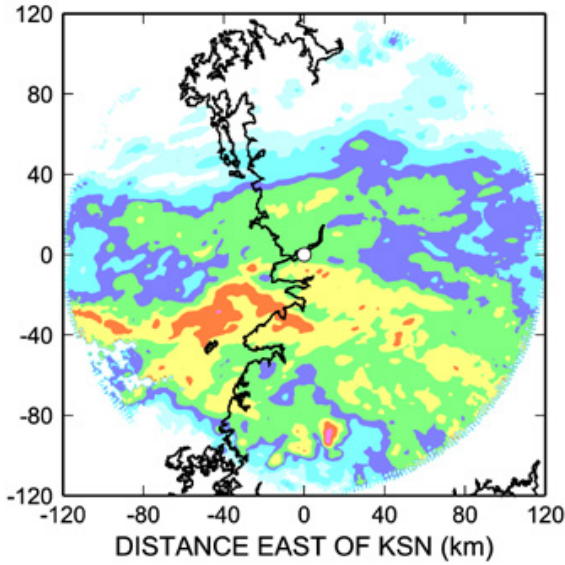

(c) 22:30 LST 09 JULY 2007 2km CAPPI

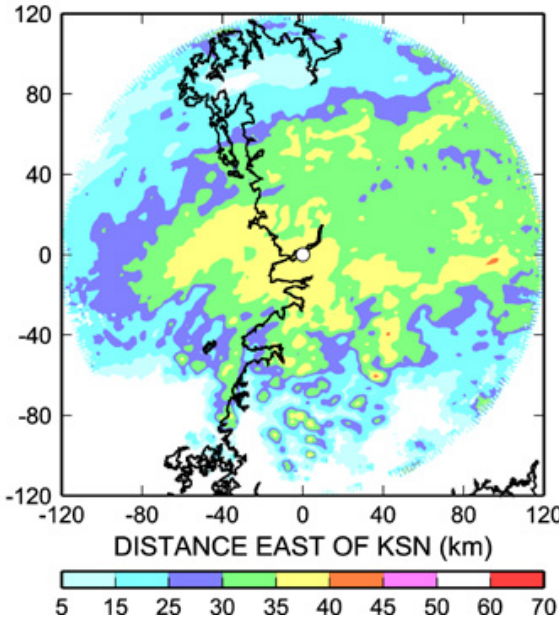

Fig. 10. Horizontal distribution of reflectivity at $2 \mathrm{~km}$ a.s.1. for (a) 18:30 LST, (b) 20:30 LST, and (c) 22:30 LST on 9 July 2007.
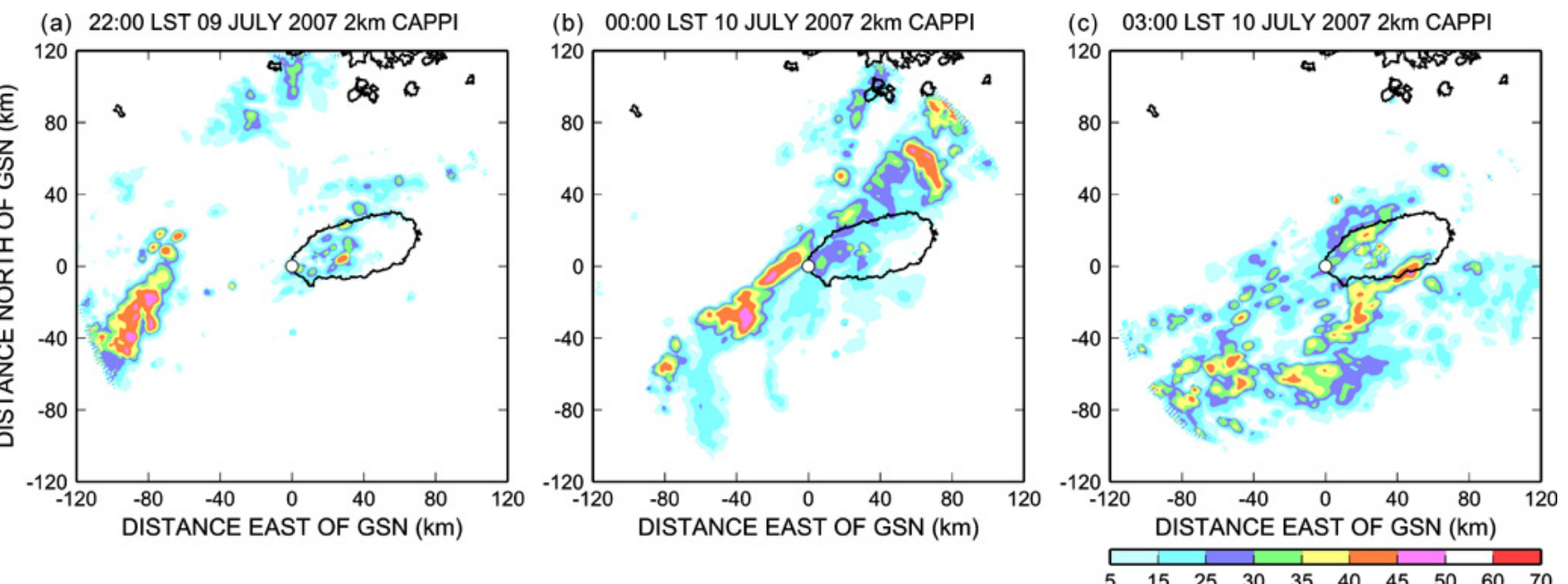

Fig. 11. Same as Fig. 9 but for (a) 22:00 LST, (b) 00:00 LST, and (c) 03:00 LST from 9 to 10 July 2007.

for 22:00 LST, 9 July to 03:00 LST, 10 July. The convective cells moved within the prefrontal warm sector ahead of the cold front. Each isolated convective cell propagated continually along the line. Small but violent convective cells occurred sequentially over the ocean (Fig. 11a-c). The maximum reflectivity was $45 \mathrm{dBZ}$ as convective cells passed over the GSN radar site at 00:00 LST and persisted during 2-h (Fig. 11b). Convective cells formed and developed over the ocean in a linear convective system with horizontal dimensions of $45 \mathrm{~km} \times 20 \mathrm{~km}$. During this period, $\mathrm{SM} \beta C$ C moved northeastward with a speed of $20.8 \mathrm{~m} \mathrm{~s}^{-1}$, which was greater than that of NM $\alpha \mathrm{CS}$.

To clarify the development processes of the convective systems, three-dimensional distributions of both reflectivity and wind at $2 \mathrm{~km}$ a.s.l. are analysed and it is depicted in Fig. 12. The convective cells developed within the stratiform cloud at around 20:10 LST, 9 July in the western coastal re- gion and coincided with the change in the wind direction from southwesterly to southeasterly. Accordingly, the windshift line formed in the rear edge of convective cells. Corresponding to sub-synoptic analysis, the southwesterly flow of moist unstable air was identified with the vectors toward the strong convective region $(\geq 40 \mathrm{dBZ})$ to the south of the wind-shift line. In addition, new cells were formed where an area of southeasterly flow was indicated at the eastern leading edge of the mature convective cell. Thus, the wind shear plays an important role in developing convective cells and generating new convective cells.

The vertical cross-sections $\left(\mathrm{A}-\mathrm{A}^{\prime}\right.$ and $\left.\mathrm{B}-\mathrm{B}^{\prime}\right)$ were shown in Fig. 13. The reflectivity indicated that the strong convective area reached $5 \mathrm{~km}$ a.s.l. The wind directions are indicated as positive (westerly) and negative (easterly). Strong easterly flows were observed, although the westerly flow appeared over $4 \mathrm{~km}$ a.s.l. A southeasterly wind played a role 


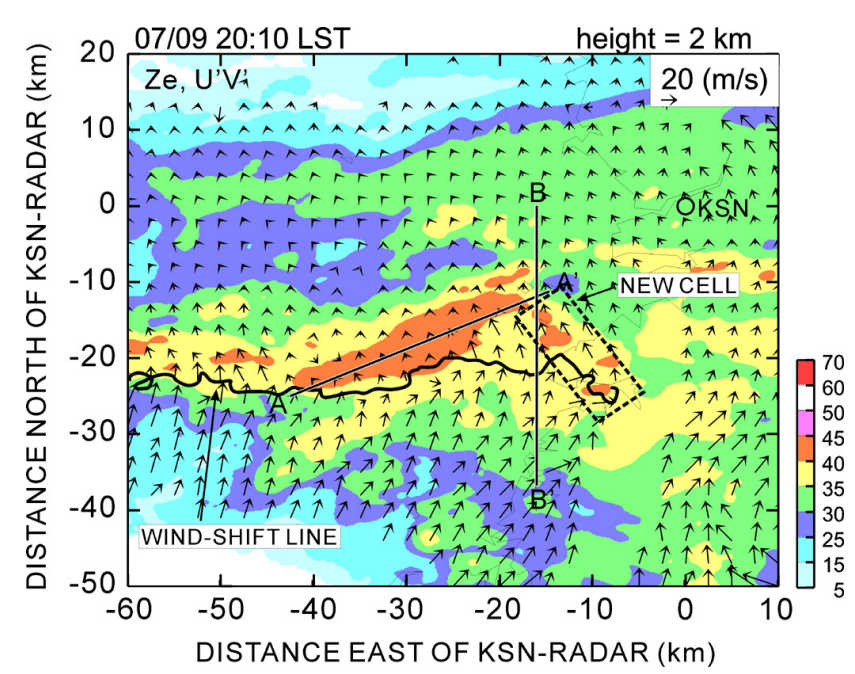

Fig. 12. Horizontal distributions of reflectivity and system relative wind vector at $2 \mathrm{~km}$ a.s.1. at 20:10 LST, 9 July 2007. The bold lines indicate the vertical cross-sections in Fig. 13.

in enhancing the $\mathrm{NM} \alpha \mathrm{CS}$, through the lifting of the strong southwesterly inflow. Not only convective updrafts of about $6 \mathrm{~m} \mathrm{~s}^{-1}$ for $X^{\prime}=30-35 \mathrm{~km}$, but also a new convective cell was generated at $X^{\prime}=30 \mathrm{~km}$ (Fig. 13b), where a strong southeasterly flow $\left(\geq 20 \mathrm{~m} \mathrm{~s}^{-1}\right)$ existed in the lower troposphere.

The moderate-to-high vertical wind shear in the convective cell led to slow movement and halted the decay of the convective system. Shear at low-to-medium levels has been reported by Parker and Johnson (2004) as an important factor in the maintenance of convective systems, which may be a reason for the extended lifetime of NM $\alpha$ CS. Such a vertical wind shear was also observed in past studies on a convective system along Meiyu/Baiu frontal regions (Ogura et al., 1985; Ishihara et al., 1995; Yamada et al., 2003; Zhou, 2009). They described that convective systems formed on the shear line, a southwesterly jet was prevalent in the low troposphere. However, the developmental processes could be different compared with previous studies. In this study, the $\mathrm{NM} \alpha \mathrm{CS}$ was developed on the wind shift line between southwesterly and southeasterly flows to the north of the warm front. Convectively-unstable air in southwesterly wind was lifted up to the area where the southeasterly wind dominated, hence, wind shear found to play a role in moisture supply over the warm front.

The isolated meso- $\beta$-scale convective cells $(\mathrm{SM} \beta \mathrm{CS}$ ) moved within the warm sector ahead of the cold front. At 23:50 LST, the developed convective cells merged over the southwestern area of the Korean Peninsula. Although the scale was slightly small, the maximum reflectivity was over $45 \mathrm{dBZ}$, greater than that of $\mathrm{NM} \alpha \mathrm{CS}$. Moreover, in contrast to $\mathrm{NM} \alpha \mathrm{CS}$, a small horizontal wind shear from southwest-

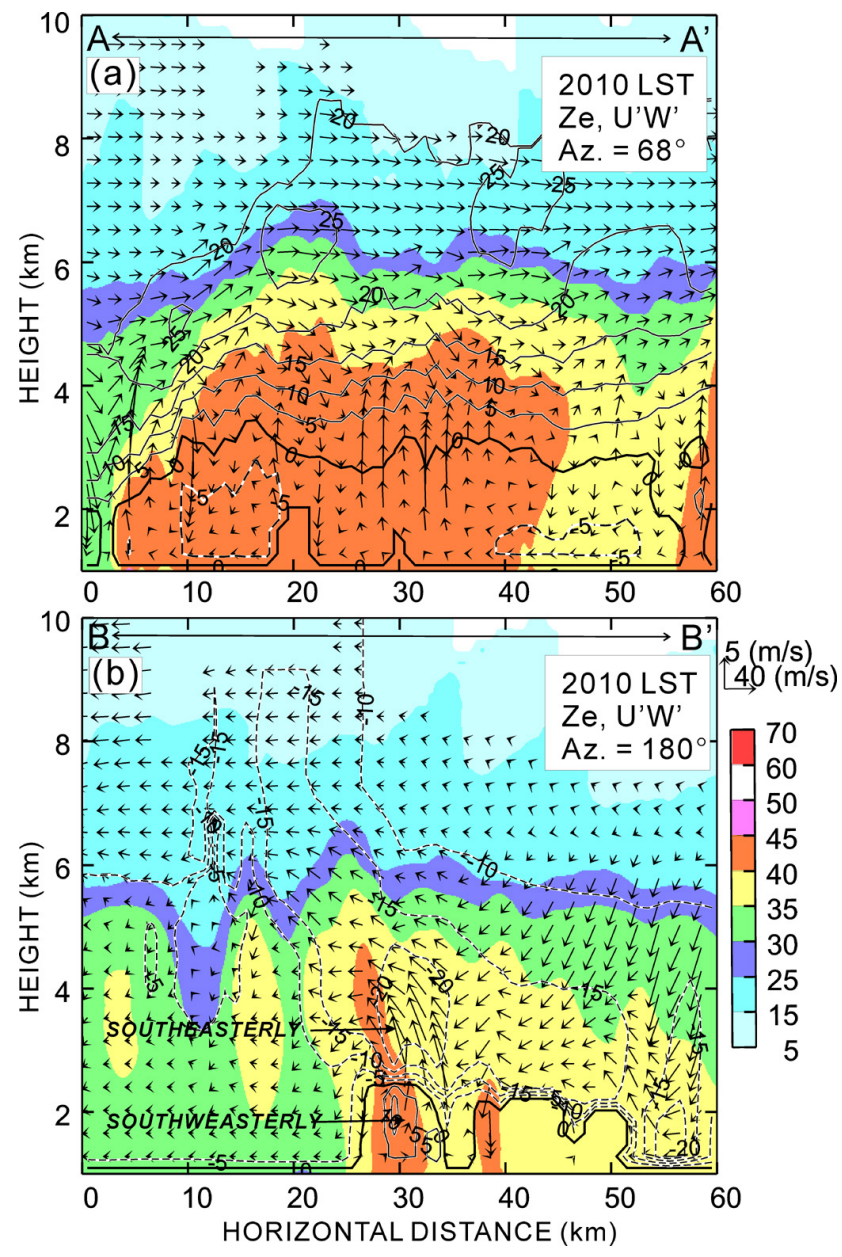

Fig. 13. Reflectivity and wind pattern in the vertical cross sections $\left(\mathrm{A}-\mathrm{A}^{\prime}\right.$ and $\left.\mathrm{B}-\mathrm{B}^{\prime}\right)$ at 20:10 LST, 9 July 2007. The bold lines indicate the interfaces with no horizontal wind through the section plane. The solid (dashed) contours indicate the positive (negative) velocities of horizontal winds into (out of) the section plane.

erly to westerly flows existed around the convective cells with warm moist air (Fig. 14).

To examine the flow pattern of SM $\beta C S$, the vertical crosssections along lines $\mathrm{C}-\mathrm{C}^{\prime}$ and $\mathrm{D}-\mathrm{D}^{\prime}$ were measured, as shown in Fig. 14. Convective cells developed and grew above $10 \mathrm{~km}$ at 23:50 LST, 9 July and strong southwesterly flow of convectively unstable air was observed at rear edge of convective cells. The southern Korean Peninsula was almost saturated and corresponded to $850 \mathrm{hPa}$ in the sub-synoptic analysis of the moisture field (shown in Fig. 7b). The strong moisture and thermal gradients may have resulted from the antecedent $\mathrm{SM} \beta \mathrm{CS}$, which dominated the strong reflectivity core (Fig. 15a). In addition, the southwesterly wind was the transport of the high $\theta_{\mathrm{e}}$ in the low-to-mid troposphere. Hence, an air surrounding high $\theta_{\mathrm{e}}$ ascended at the surface cold front and formed line convection. It seems reasonable to infer that this updraft resulted from the convectively unstable 


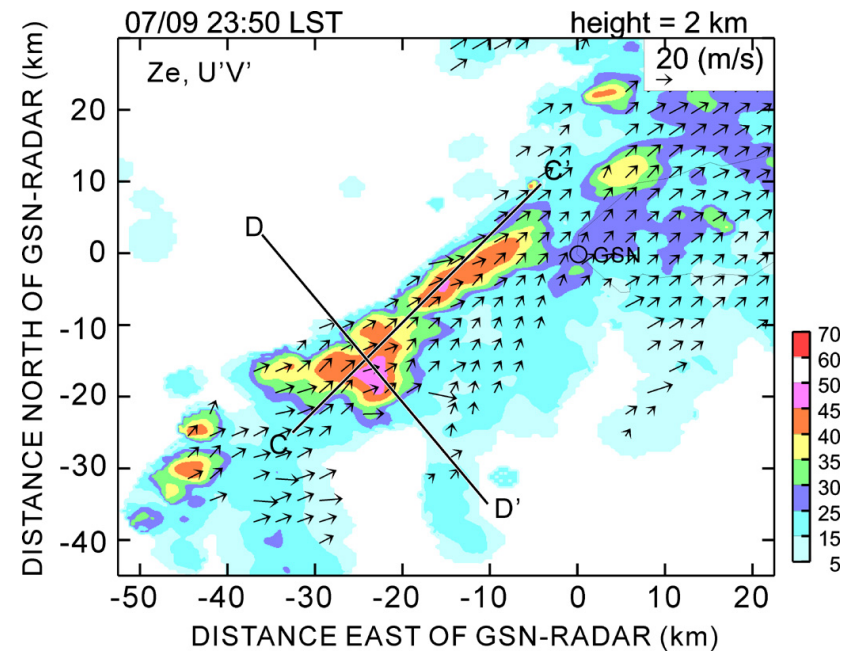

Fig. 14. Same as Fig. 12, but for 23:50 LST, 9 July 2007. The bold lines indicate the vertical cross-sections in Fig. 15.

air of the southwesterly flow (Fig. 15b). The updraft and downdraft into the strong convective region were at $9.5 \mathrm{~m} \mathrm{~s}^{-1}$ and $11 \mathrm{~m} \mathrm{~s}^{-1}$, respectively. Under these circumstances, shortlived but strong convective cells occurred successively over the ocean.

\section{Summary and conclusions}

Based on Doppler radar data, sub-synoptic data and upper-air soundings on 9-10 July 2007 , this study presents the environmental conditions on two different types of MCSs in determining their morphologies over Korea. The sub-synoptic structure and evolution along the front were analysed using MTSAT-IR and MANAL data. A variational method was used to extract three-dimensional wind fields from the Sband Doppler radar data of operational stations KSN, GSN and JNI.

The locally different rainfall amounts recorded over the central and southern areas of the Korean Peninsula. The northern meso- $\alpha$-scale convective system (NM $\alpha \mathrm{CS})$ passed over central area from 15:00 LST, 9 July to 06:00 LST, 10 July. Following $\mathrm{NM} \alpha \mathrm{CS}$, a southern meso- $\beta$-scale convective system (SM $\beta \mathrm{CS}$ ) moved over the southern area from 22:00 LST, 9 July to 06:00 LST, 10 July.

During the cases period, the Changma front elongated from China to Japan and moved northeastward. The warm front formed with an east-west orientation within the windshift line, with southeasterly and southwesterly winds to the north and south, respectively. In the vertical crosssection across the warm front, cross-frontal horizontal wind shear below $500 \mathrm{hPa}$ strengthened due to prefrontal eastsoutheasterly flow. The GJ sounding yielded the bulk shear of $3.6 \times 10^{-3} \mathrm{~s}^{-1}$ for $0-6 \mathrm{~km}$. Supercell-like storm processed the vertical wind shear of $4.2 \times 10^{-3} \mathrm{~s}^{-1}$ from surface to $5 \mathrm{~km}$

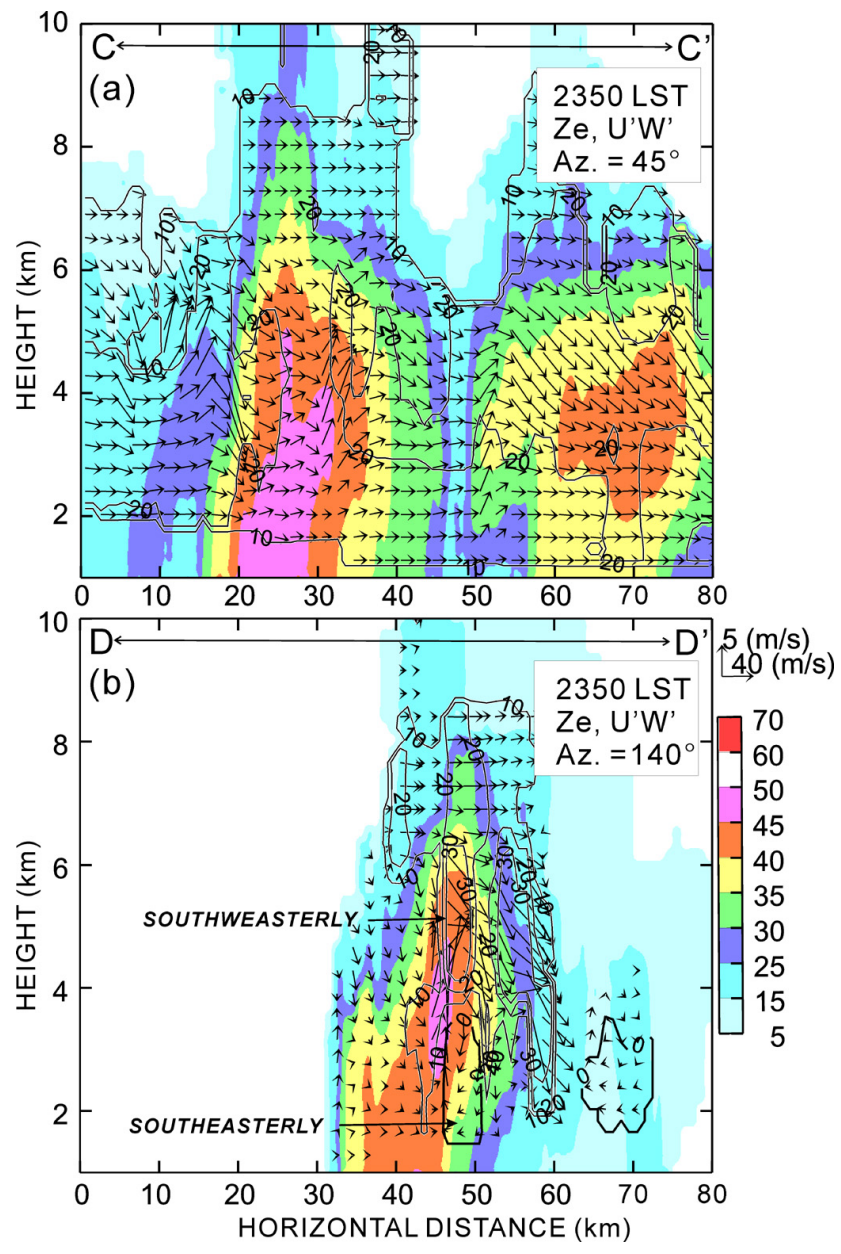

Fig. 15. Same as Fig. 13, but for 23:50 LST, 9 July 2007.

in moist environment (Shimizu et al., 2008). The cold front near the low pressure was aligned from northeast to southwest, moreover strong southwesterly $\left(\geq 20 \mathrm{~m} \mathrm{~s}^{-1}\right)$ prevailed around cold front.

The surface low pressure intensified and moved with Changma front. The enhanced low pressure accelerated the LLJ with maxima of $\geq 27 \mathrm{~m} \mathrm{~s}^{-1}$, clearly exceeding the criterion of $12.5 \mathrm{~m} \mathrm{~s}^{-1}$ for an LLJ (Chen and Yu, 1988), strong LLJ transported warm moist air mainly at $850 \mathrm{hPa}$. Moisture transport vectors revealed that a strong transport of moisture along the cold front in the high equivalent potential temperature region $(\geq 350 \mathrm{~K})$. In vertical cross-section across the cold front, the moisture was largely and deeply advected into the sloping frontal zone. The wet environment in the middle troposphere increased the amount of water that can be condensed and precipitated. Hence, the precipitation efficiency was clearly difference between $\mathrm{NM} \alpha \mathrm{CS}$ and $\mathrm{SM} \beta \mathrm{CS}$.

According to three-dimensional kinematic and reflectivity structures in the cases of NM $\alpha \mathrm{CS}$, meso- $\alpha$ - and multi-scale convective systems were apparently embedded within an area of stratiform clouds north of the warm front. The horizontal 
and vertical wind flows were different in that the southwesterly wind blew at the back of the convective system while the southeasterly wind appeared over the convective region where the new cell was generated. The southeasterly wind played an important role in uplifting such strong southwesterly with warm and moist air to north of warm front. The vertical wind shear was also observed in past studies on the convective systems along Meiyu/Baiu frontal regions (Ogura et al., 1985; Ishihara et al., 1995; Yamada et al., 2003; Zhou, 2009). As a result of the wind distribution, the convective systems slowly propagated near the western coastal region and led to heavy rainfall over the central Korean Peninsula for 4-h in long-lived convective systems.

In SM $\beta$ CS, isolated convective cells (meso- $\beta$ scale) developed ahead of the cold front within a prefrontal warm sector. Convective cells rapidly developed and had short lifetimes in the ocean. Strong southwesterly flow under convectively unstable air was prevailed around convective cells. Corresponding to the moisture field at $850 \mathrm{hPa}$ in the subsynoptic analysis, the southern area of the Korean Peninsula was almost saturated. The strong moisture advection and high thermal gradients may have resulted from the antecedent $\mathrm{SM} \beta \mathrm{CS}$. The relatively unstable air flowed into the updraft flow $\left(9.5 \mathrm{~m} \mathrm{~s}^{-1}\right)$ and downdraft flow $\left(11 \mathrm{~m} \mathrm{~s}^{-1}\right)$ near the strong convective regions. Although this convective system was smaller than that in $\mathrm{NM} \alpha \mathrm{CS}$, its maximum reflectivity and translational speed were stronger and faster than those of NM $\alpha \mathrm{CS}$.

The results obtained here successfully explain the evolution of the Changma front with surface low pressure and the morphological features that maintain different types of convective systems over the central and southern areas of the Korean Peninsula. This study proves that the convective systems had different environments in their morphology. However, further studies based on additional statistical analysis are required to prove the complex mechanism by which MCSs produce heavy rainfall events.

Acknowledgements. The authors thank the anonymous reviewers for their constructive comments, which have helped to improve the quality of the paper. This research was supported by the National Research Foundation of Korea (NRF) through a grant provided by the Korean Ministry of Education, Science \& Technology (MEST) in 2012 (No. K201200037). This research was also partially supported by the Korea MeteorologicalAdministration Research and Development Programunder Grant CATER 2012-2071.

Topical Editor P. M. Ruti thanks two anonymous referees for their help in evaluating this paper.

\section{References}

Akiyama, T.: A medium-scale cloud cluster in a Baiu front. Part I: Evolution process and a fine structure, J. Meteorol. Soc. Japan, $62,485-504,1984 a$.
Akiyama, T.: A medium-scale cloud cluster in a Baiu front. Part II: Thermal and kinematics fields and heat budget, J. Meteorol. Soc. Japan, 62, 505-520, 1984b.

Bluestein, H. B.: Synoptic-Dynamic Meteorology in Midlatitudes, vol. 2, Oxford University Press, 594, 1993.

Bluestein, H. B. and Jain, M. H.: Formation of mesoscale lines of precipitation: Severe squall lines in Oklahoma during the spring, J. Atmos. Sci., 42, 1711-1732, 1985.

Carbone, R. E.: A severe frontal rainband. Part I. Stormwide hydrodynamic structure, J. Atmos. Sci., 39, 258-279, 1982.

Chen, G. T.-J.: Observational aspects of the Mei-Yu phenomena in subtropical China, J. Meteorol. Soc. Japan, 61, 306-312, 1983.

Chen, G. T.-J. and Chang, C. P.: The structure and vorticity budget of an early summer monsoon trough (Mei-Yu) over southeastern China and Japan, Mon. Weather Rev., 108, 942-953, 1980.

Chen, G. T.-J. and Yu, C. C.: Study of low-level jet and extremely heavy rainfall over northern Taiwan in the Mei-Yu Season, Mon. Weather Rev., 116, 884-891, 1988.

Chen, G. T.-J., Wang, C. C., and Wang, A. H.: A case study of subtropical frontogenesis during a blocking event, Mon. Weather Rev., 135, 2588-2608, 2006.

Cressman, G. P.: An operational objective analysis system, Mon. Weather Rev., 87, 367-374, 1959.

Ćurić, M., Janc, D., and Vučković, V.: The influence of merging and individual storm spiltting on mesoscale convective system formation, Atmos. Res., 93, 21-29, 2009.

Ding, Y. H.: Summer monsoon rainfalls in China, J. Meteorol. Soc. Japan, 70, 373-396, 1992.

Gao, J., Xue, M., Shaphiro, A., and Droegemeier, K. K.: A variational method for the analysis of three-dimensional wind fields from two Doppler radars, Mon. Weather Rev., 127, 2128-2142, 1999.

Geng, B., Yamada, H., Reddy, K. K., Uyeda, H., and Fujiyoshi, Y.: An observational study of the development of a rainband on a Meiyu front causing heavy rainfall in the downstream region of the Yangtze River, J. Meteorol. Soc. Japan, 82, 1095-1115, 2004.

Houze, R. A. and Cheng, C. P.: Inclusion of Mesoscale Updrafts and Downdrafts in Computations of Vertical Fluxes by Ensembles of Tropical Clouds, J. Atmos. Sci., 38, 1751-1770, 1981.

Ishihara, M., Fujiyoshi, Y., Tabata, A., Sakakibara, H., Akaeda, K., and Okamura, H.: Dual Doppler radar analysis of an intense mesoscale rainband generated along the Baiu front in 1988: Its kinematical structure and maintenance process, J. Meteorol. Soc. Japan, 73, 139-163, 1995.

Kim, H. W. and Lee, D. K.: An observational study of mesoscale convective systems with heavy rainfall over the Korean Peninsula, Wea. Forecasting, 21, 125-148, 2006.

Lee, D. K., Kim, H. R., and Hong, S. Y.: Heavy rainfall over Korea during 1980-1990, Kor. J. Atmos. Soc., 1, 32-50, 1998.

LeMone, M. A.: Momentum and mass transport by a line of cumulonimbus, J. Atmos. Sci., 40, 1815-1834, 1983.

LeMone, M. A., Zipser, E. J., and Trier, S. B.: The role of environmental shear and thermodynamic conditions in determining the structure and evolution of mesoscale convective systems during TOGA COARE, J. Atmos. Sci., 55, 3493-3518, 1998.

McBean, G. A. and Stewart, R. E.: Structure of a frontal systems over the northeast Pacific Ocean, Mon. Weather Rev., 119, 9971013, 1991. 
Moteki, Q., Uyeda, H., Maesaka, T., Shinoda, T., Yoshizaki, M., and Kato, T.: Structure and development of two merged rainbands observed over the East China Sea during X-BAIU-99 Part I: Meso- $\beta$-scale structure and development processes, J. Meteor. Soc. Japan, 82, 19-24, 2004.

Mueller, C. K., Wilson, J. W., and Crook, N. A.: The utility of sounding and mesonet data to nowcast thunderstorm initiation, Wea. Forecasting, 8, 132-146, 1993.

Ninomiya, K. and Akiyama, T.: Multi-scale features of Baiu, the summer monsoon over Japan and the East Asia, J. Meteor. Soc. Japan, 70, 467-495, 1992.

Ogura, T., Asai, T., and Dohi, K.: A case study of a heavy precipitation event along the Baiu front in northern Kyushu, 23 July 1982: Nagasaki heavy rainfall, J. Meteor. Soc. Japan, 63, 883900, 1985

Park, S. U., Yoon, I. H., and Chung, S. K.: Heat and moisture sources associated with Changma front during the summer of 1987, J. Korean Meteor. Soc., 22, 1-27, 1986 (in Korean).

Parker, M. D. and Johnson, R. H.: Structures and dynamics of quasi2D mesoscale convective systems, J. Atmos. Sci., 61, 545-567, 2004.

Ray, P. S., Ziegler, C. L., Bumgarner, W., and Serafin, R. J.: Singleand Multiple-Doppler radar observations of tornadic stroms, Mon. Weather Rev., 108, 1607-1625, 1980.

Shapiro, M. A. and Keyser, D. A.: Fronts, jet streams, and the tropopause, in: Extratropical Cyclones: The Erik Palmën Memorial Volume, edited by: Newton, C. W. and Holopainen, E. O., Amer. Meteor. Soc., 167-191, 1990.

Shimizu, S., Uyeda, H., Moteki, Q., Maesaka, T., Takaya, Y., Akaeda, K., Kato, T., and Yoshizaki, M.: Structure and formation mechanism on the 24 May 2000 supercell-like storm developing in a moist environment over the Kanto Plain, Japan, Mon. Weather Rev., 136, 2389-2407, 2008.
Shin, C. S. and Lee, T. Y.: Development mechanisms for the heavy rainfalls of 6-7 August 2002 over the middle of the Korean Peninsula, J. Meteorol. Soc. Japan, 83, 683-709, 2005.

Shinoda, T. and Uyeda, H.: Effective factors in the development of deep convective clouds over the wet region of eastern China during the summer monsoon season, J. Meteorol. Soc. Japan, 80, 1395-1414, 2002.

Shinoda, T., Uyeda, H., and Yoshimura, K.: Structure of moist layer and sources of water over the southern region far from the Meiyu/Baiu front, J. Meteor. Soc. Japan, 83, 137-152, 2005.

Sun, J. and Lee, T. Y.: A numerical study of an intense quasistationary convection band over the Korean Peninsula, J. Meteor. Soc. Japan, 80, 1221-1245, 2002.

Takahashi, N., Uyeda, H., Kikuchi, K., and Iwanami, K.: Mesoscale and convective scale features of heavy rainfall events in late period of the Baiu season in July 1988, Nagasaki Prefecture, J. Meteor. Soc. Japan, 74, 539-561, 1996.

Thompson, R. L. and Edwards, R.: An overview of environmental conditions and forecast implications of the 3 May 1999 tornado outbreak, Wea. Forecasting, 15, 682-699, 2000.

Yamada, H., Geong, B., Reddy, K. K., Uyeda, H., and Fujiyoshi, Y.: Three-dimensional structure of a mesoscale convective system in a Baiu-frontal depression generated in the downstream region of the Yangtze River, J. Meteorol. Soc. Japan, 81, 1243-1271, 2003.

You, C. H., Lee, D. I., Jang, S. M., Jang, M., Uyeda, H., and Shinoda, T.: Characteristics of rainfall systems accompanied with Changma front at Chujado in Korea, Asia-Pacific, J. Atmos. Sci., 46, 41-51, 2010.

Zhou, H.: Study on the mesoscale structure of the heavy rainfall on Meiyu front with dual-Doppler radar, Atmos. Res., 93, 335-357, 2009 . 